\title{
AGE RELATED MICROSCOPIC CHANGES ON ISLETS OF LANGERHANS IN HUMAN PANCREAS
}

\author{
Latha Sreedhar Lekshmi Sreedhar1, Aswathy Mariya Oommen², Suja Robert Sarasammal ${ }^{3}$
}

${ }^{1}$ Associate Professor, Department of Anatomy, Government Medical College, Trivandrum.

${ }^{2}$ Assistant Professor, Department of Anatomy, Government Medical College, Trivandrum.

${ }^{3}$ Assistant Professor, Department of Anatomy, Government Medical College, Trivandrum.

\section{BACKGROUND}

ABSTRACT

The islets of Langerhans is an important endocrine gland, which regulate the blood glucose level. The rise in the blood glucose level results in diabetes mellitus, an age old disease which affects all the systems of our body. Nowadays, an increase in the incidence of diabetes is noticed in younger age groups also. The increased intake of alcohol in our state also affects the gland. Scientific advancement like islet transplantation makes most of them correctable. So we found it is very important to assess the age related changes in the islets of Langerhans.

\section{MATERIALS AND METHODS}

Sixty two autopsied specimens of pancreas in an age range from 6 months to 83 years were collected for analysis from the mortuary of Government Medical College, Thiruvananthapuram, Kerala. Histological examination of the glands was done in the Histology Laboratory of Department of Anatomy, Government Medical College, Thiruvananthapuram, Kerala.

\section{RESULTS}

A significant association between age and diameter of islets were observed in the present study. The number and size of beta cells showed a gradual increase up to 40 years, thereafter the cell number decreased considerably. In a chronic alcoholic patient, hyperplasia of islets and deposition of amyloids within the islets were observed.

\section{CONCLUSION}

The number of beta cells decreased after the age of 40 years. The beta cell destruction may be due to chemicals, diet, genetic factors and autoimmune diseases. The decrease in the number of beta cells result in type I diabetes mellitus.

\section{KEYWORDS}

Human Pancreas, Islets of Langerhans, Beta Cells Diabetes Mellitus.

HOW TO CITE THIS ARTICLE: Sreedhar LSL, Oommen AM, Sarasammal SR. Age related microscopic changes on Islets of Langerhans in human pancreas. J. Evolution Med. Dent. Sci. 2016;5(102):7463-7468, DOI: 10.14260/jemds/2016/1690

\section{BACKGROUND}

Diabetes Mellitus is an age old problem for which there is no complete cure. Recently, the incidence of diabetes mellitus increased and it occurred even in young age groups. Research studies have reached a stage where islet cell transplants are being tried. The aim of the present study is to find out whether there is any regular change occurring in the islets as age advances.

Most of the histological studies are limited to the pancreas of animals like sheep, rat, etc. Very few studies are done on human pancreas and that too in specific age groups. In the present study, the microscopic changes of islets are correlated with different age groups.

In recent studies, five types of cells are identified in the islets. Researchers have also observed that autoimmune diseases, blood cholesterol levels, HbA1C viruses and chemicals also have a role in blood glucose level. Hence, the age related changes in islets and in particular in the Beta cells at cellular level will be useful to both endocrinologists and gastroenterologists.

Financial or Other, Competing Interest: None.

Submission 15-11-2016, Peer Review 29-11-2016,

Acceptance 15-12-2016, Published 22-12-2016.

Corresponding Author:

Dr. Latha Sreedhar Lekshmi Sreedhar,

Department of Anatomy,

Government Medical College, Trivandrum.

E-mail:drlathals@gmail.com

DOI: $10.14260 /$ jemds $/ 2016 / 1690$

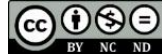

\section{MATERIALS AND METHODS}

The materials used for the present study were collected from human autopsies of the Mortuary of Government Medical College, Thiruvananthapuram, Kerala. The tissue samples were taken from the tail end of the pancreas, where islets are concentrated more.

\section{Inclusion Criteria}

Since autolysis of pancreas is rapid, samples were collected only from autopsies performed within 6 hours after death.

\section{Exculpation Criteria}

1. Autopsies performed $6 \mathrm{hrs}$. after death.

2. Crush injuries of Abdomen.

After collecting, the tissues were fixed in Bouin's fluid for 24 hours. They were then subjected to routine histological processing as per the standard procedures described by (MacManus and Moury, 1960). The paraffin blocks were serially sectioned at a thickness of 5 microns using a rotary microtome. The sections were stained with standard Haematoxylin and Eosin ( $\mathrm{H}$ and $\mathrm{E}$ ) for microscopic evaluation of the islet cells. Special stains like Fuchsin Blue, Chrome Alum Haematoxylin and Azocarmine, etc. were also employed to differentiate the various islet cells (MacManus and Moury, 1960).

The sections were observed under a binocular microscope and measurements were taken with a horizontal eyepiece micrometer called the graticule, which is calibrated with a stage micrometer. 
The diameter of islets and beta cells were measured at five different sites in a pre-observed and selected section of the gland. The data were analysed statistically.

Care was taken to collect the tissue from the bodies of which autopsies were done within 6 hours of death. It was also taken into consideration that tissues were not collected from bodies in which death occurred due to crush injury to the abdomen.

A total of 62 samples were collected from the age group of six months to 83 years and were subjected to microscopic evaluation after routine histological processing. Out of the 62 specimens studied, 3 were female specimens.

\section{RESULTS}

The samples collected for the present study were grouped as per their age (Table 2) and were in an age range from six months to 83 years. The size of islets showed a gradual increase as the age of the specimens advanced throughout samples studied (Graph). In the present study, the youngest aged sample was from a six-month-old baby in which major portions of the pancreatic segment was composed of islets and were arranged in a cord-like form as reported by Ferner (Fig. 2). A significant association between age and diameter of islets were observed in the present study. The number and size of Beta cells showed a gradual increase up to 40 years (Table 3), thereafter the cell number decreased considerably. The changes after 40 years of age were not uniform in all the cases studied.

In standard Haematoxylin and Eosin ( $\mathrm{H}$ and $\mathrm{E}$ ) staining the islets appeared as more or less spherical masses of pale staining areas, in which the cells were arranged as irregular anastomotic cords and surrounded by pancreatic acini (Fig. 1). The islets were separated from the acinar group by a thin capsule made up of reticular fibres clearly distinguished by Mallory Trichrome Stain (Fig. 7).

Majority of the cells $(65 \%-80 \%)$ detected in the present study were Beta cells, which were located in the central region; $10 \%-20 \%$ of the cells were Alpha located peripherally and were larger than Beta cells. Few Delta cells (0\% - 2\%) were also observed peripherally along with the Alpha cells (Fig. 9). In a 72-year-old man, the islets showed more number of Beta cells (Fig. 9). In a 72-year-old man, the islets showed more number of Beta cells (Fig. 10).

In a chronic alcoholic patient, the changes were segmental. One segment showed hyperplasia, while in another one a large islet group with more number of beta cells and in another segment Amyloid deposits were observed (Fig. 12, 13, 14).

Two specimens were obtained from type II diabetes patients on insulin treatment and both are in age group 51 - 60 years. Compared to the normal person of similar age group here, the diameter of islets were increased (Fig. 15).

In 3 female specimens, no microscopic changes were observed in islets compared to male islets of similar age group.

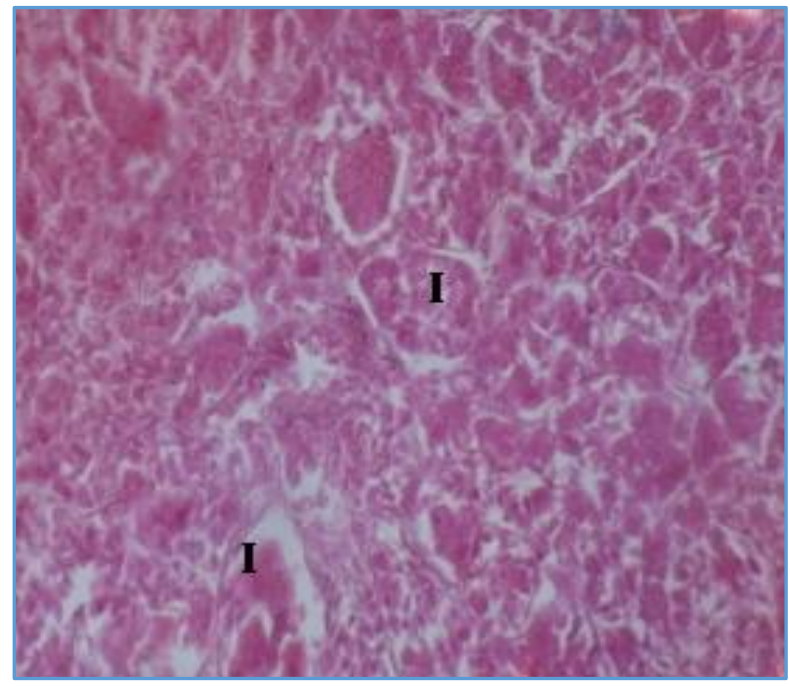

Figure 1. An Adult Pancreas $H$ and $E$ Stain (I) Islets under Low Power Objective

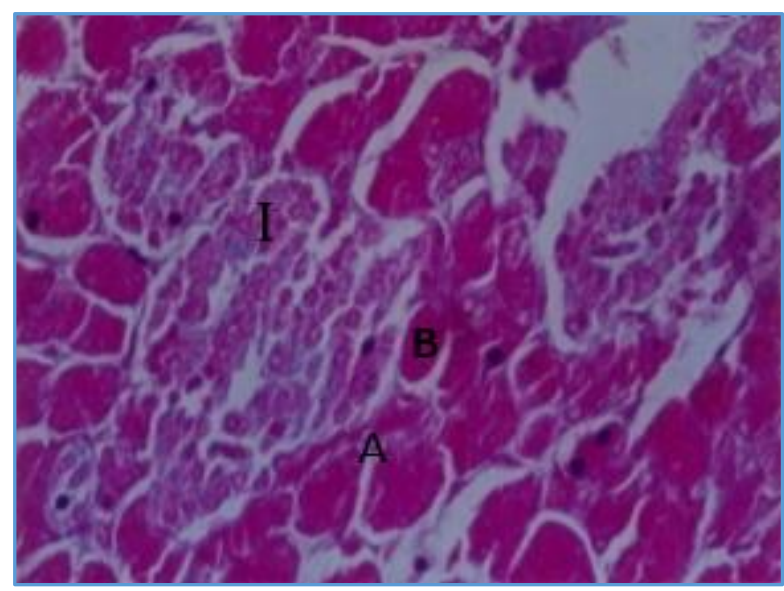

Figure 2. 6 Months Old Pancreas Mallory Heidenhains Azocarmine Stain x 200 (I) A Large Islet (B) Beta Cell (A) Alpha Cell

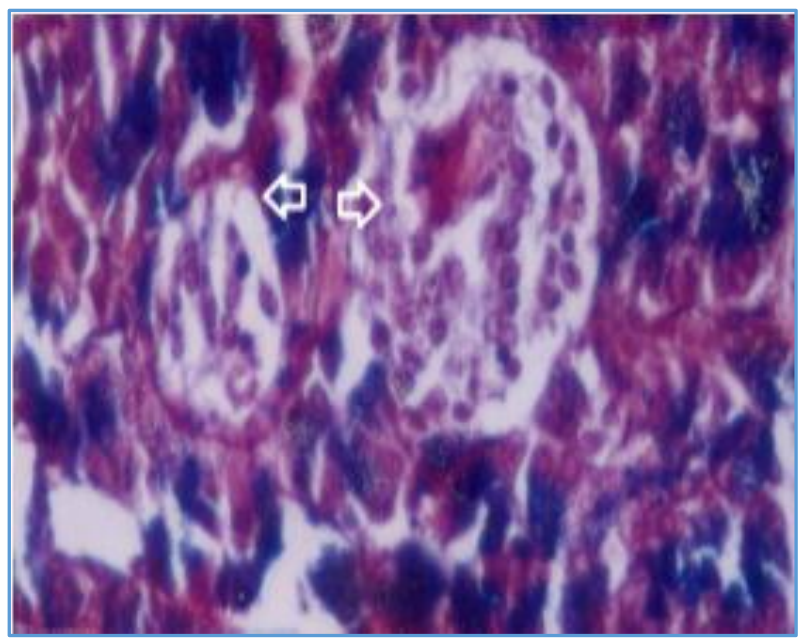

Figure 3. 7 Years Old Pancreas Mallory Phosphotungstic Acid Haematoxylin $x 400$. Arrow shows Islets with Alpha and Beta Cells 


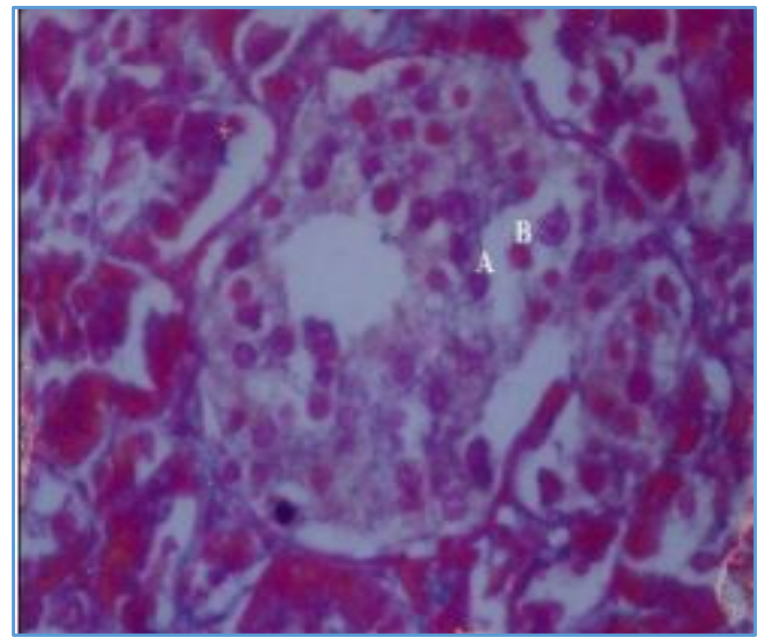

Figure 4. 18 Years Old Pancreas Mallory Heidenhains Azocarmine Stain $x$ 400, Islets with

More Number of Beta Cells (B) and (A) Alpha Cells

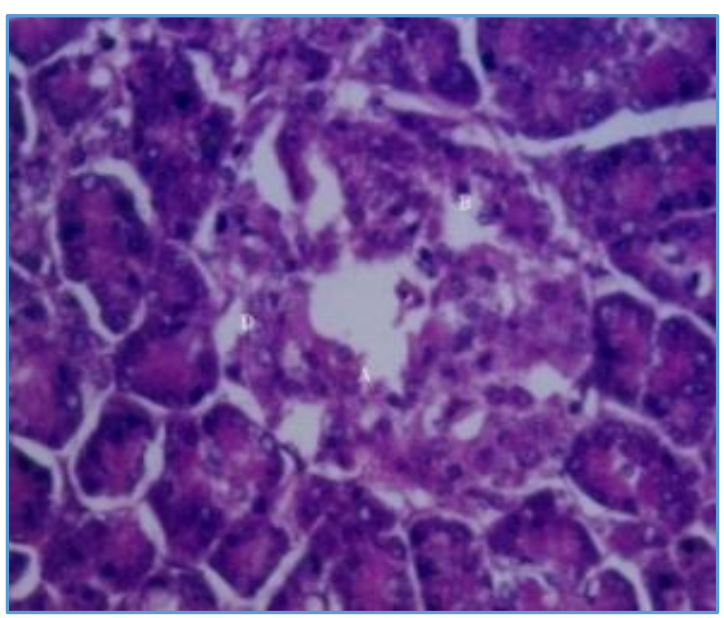

Figure 5. 28 Years of Foetal Pancreas Chrome Alum Haematoxylin Phloxine Stain $x 400$ Alpha Cells (A) Beta Cell (B) Delta Cell (D)

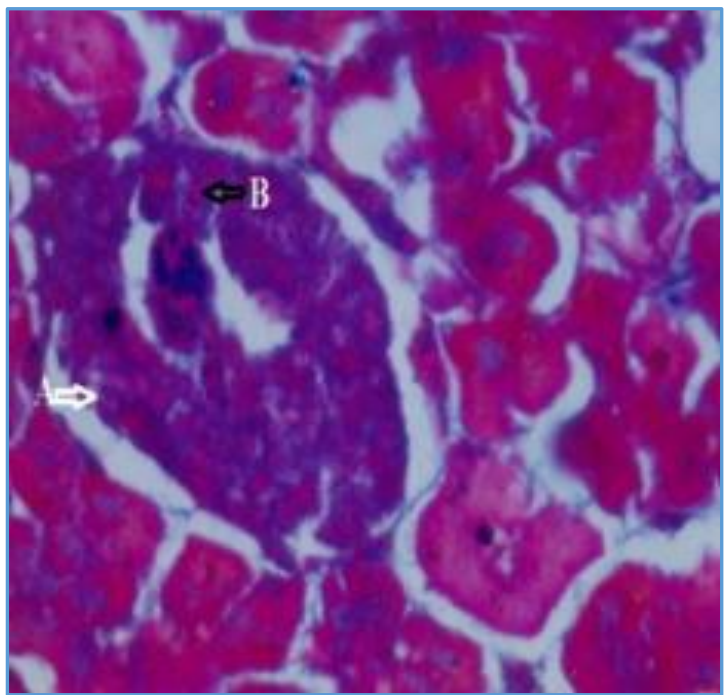

Figure 6. 38 Years Old Pancreas

Mallory Phosphotungstic Acid Haematoxylin Alpha Cell (A) Beta Cell (B)

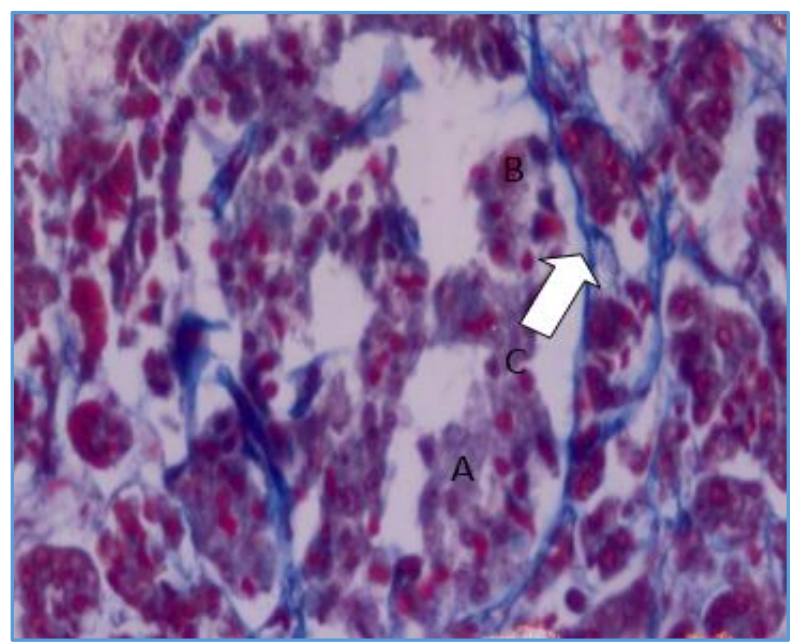

Figure 7. 47 Years Old Pancreas Mallory Trichrome Stain $x$ 400 Blue Coloured Capsule (C) (B) Beta Cell (A) Alpha Cell

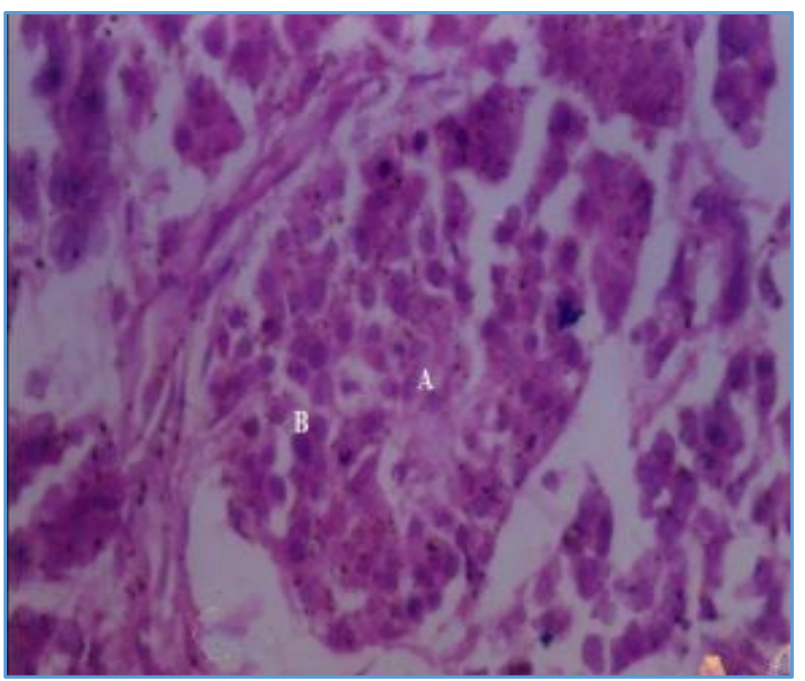

Figure 8. 55 Years Old Pancreas Azocarmine Stain $x$ 200. Islet with Alpha (A) and Beta Cell (B)

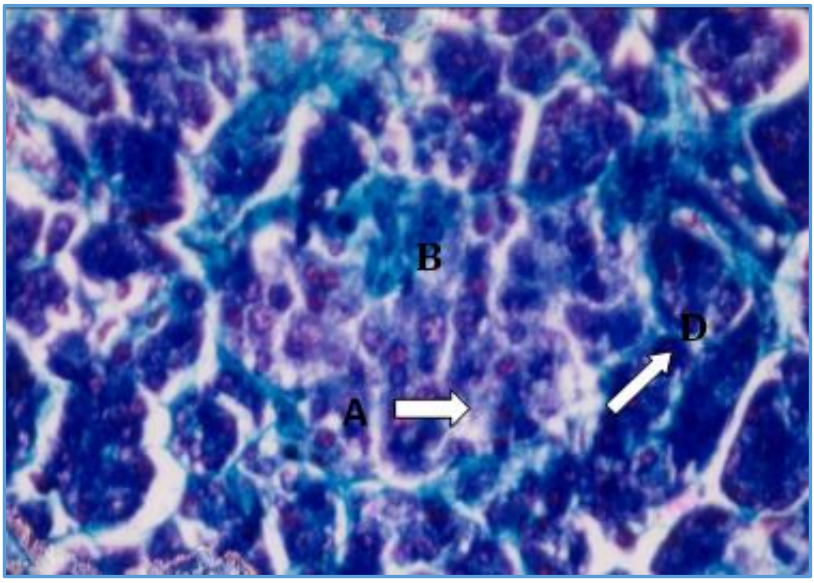

Figure 9. 61 Years Old Pancreas - Aldehyde Fuchsin Counter-Stained with Masson's Trichrome $\mathrm{x} 400$ (B) Beta Cells (A) Alpha Cells (D) Delta Cells 


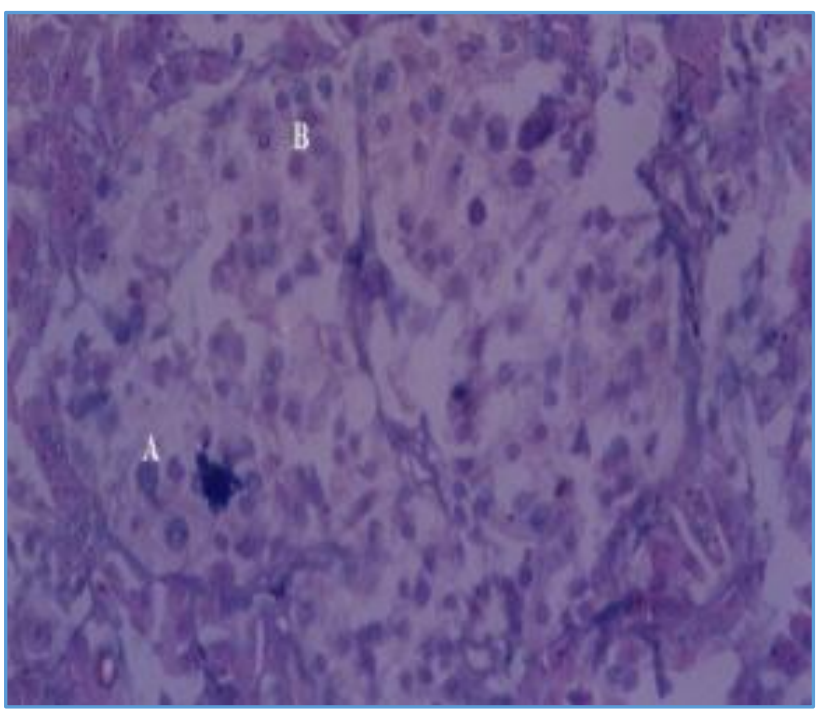

Figure 10. 72 Years Old Pancreas Chrome Alum Haematoxylin Stain $x 100$ A Large Islets with Alpha (A) and Beta Cell (B)

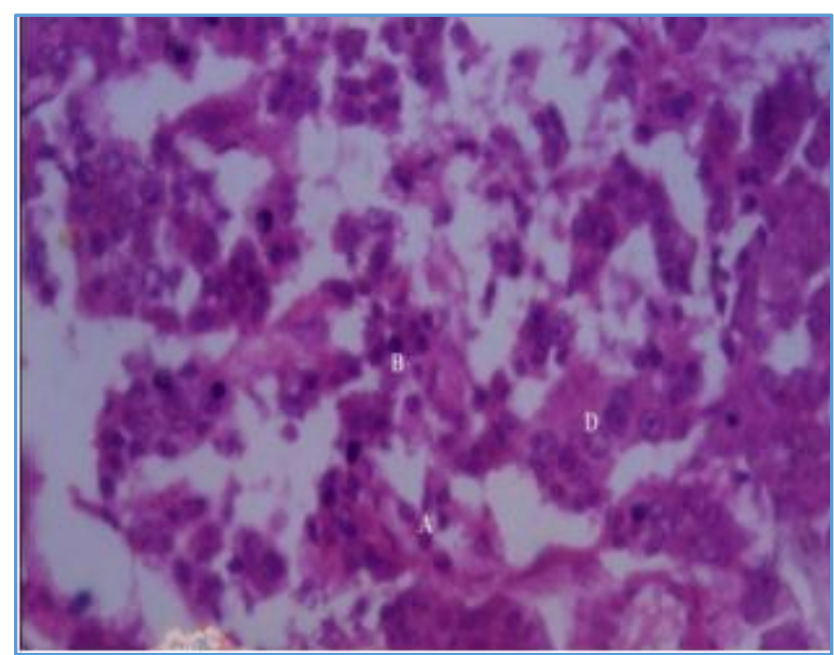

Figure 11. 83 Year Old Pancreas Azocarmine Stain x 200 (B) Beta Cell (A) Alpha Cell (D) Delta Cell

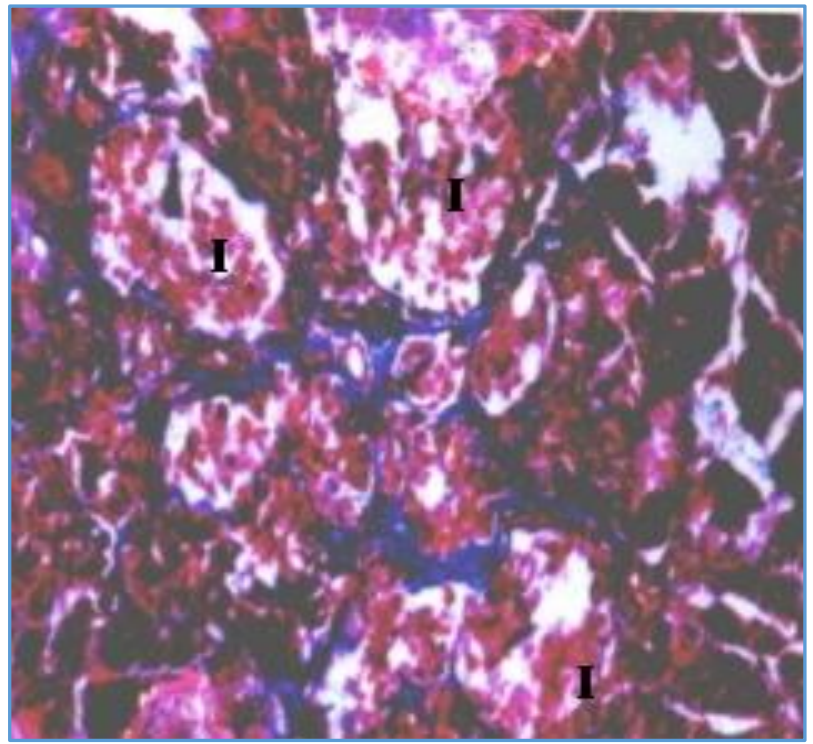

Figure 12. 38 Years Old Chronic Alcoholic Pancreas, Mallory Heidenhains Azocarmine Stain x 200. Hyperplasia of Islets (I)

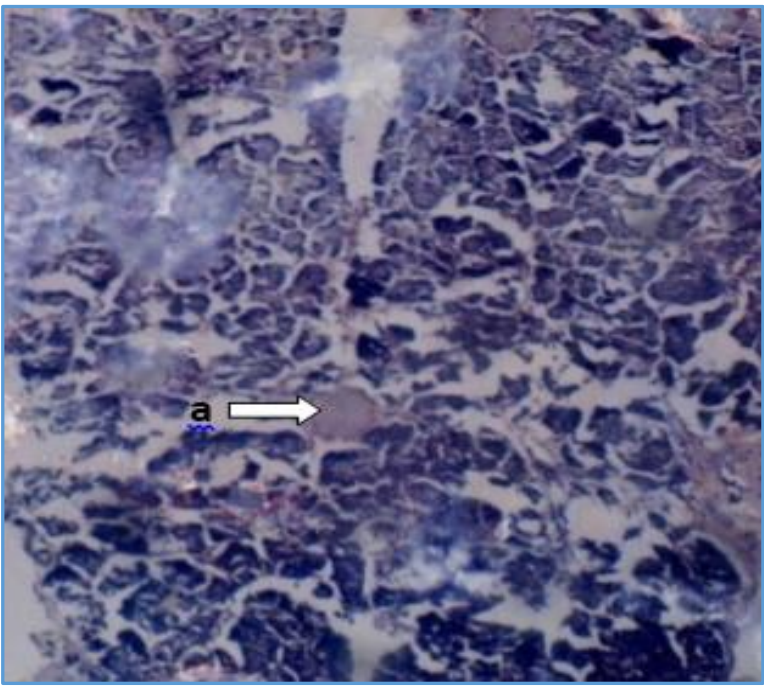

Figure 13. 38 Years Old Chronic Alcoholic Pancreas (a) Amyloid Deposit in an Islet. Congo Red Stain

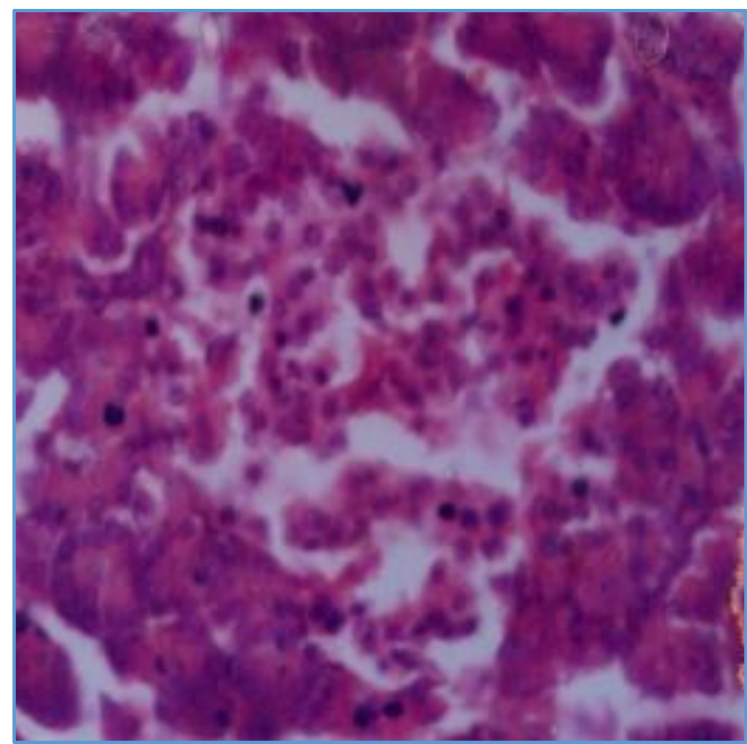

Figure 14. 38 Years Old Chronic Alcoholic Pancreas (I) Islet shows Plenty of Sinusoids Azocarmine Stain x 400

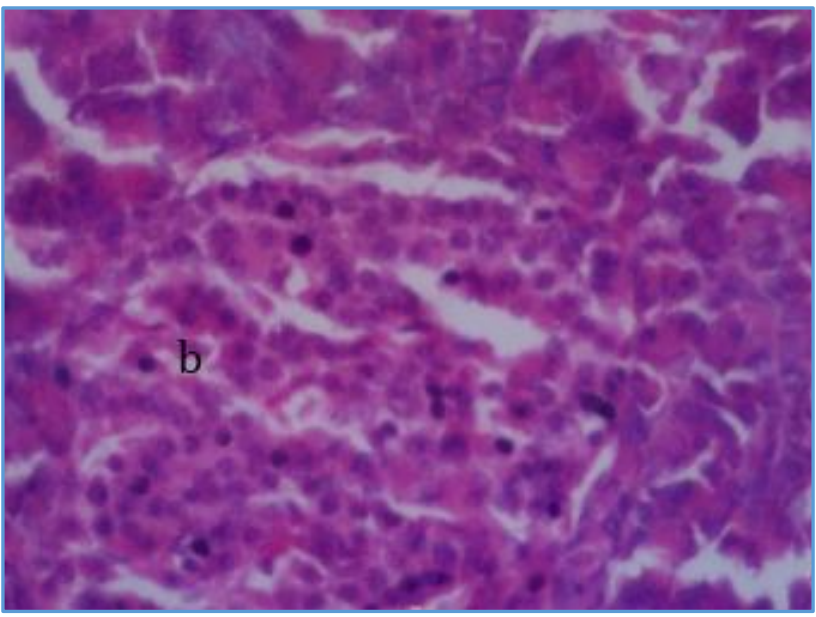

Figure 15. 55 Years Old Diabetic on Insulin Treatment, Chromealum Haematoxylin Phloxine Stain B-(Beta Cell) 


\begin{tabular}{|c|c|c|}
\hline Sl. No. & Age Group (Yrs.) & No. of Specimens \\
\hline 1 & $0-10$ & 6 \\
\hline 2 & $11-20$ & 9 \\
\hline 3 & $21-30$ & 8 \\
\hline 4 & $31-40$ & 13 \\
\hline 5 & $41-50$ & 8 \\
\hline 6 & $51-60$ & 8 \\
\hline 7 & Above 60 & 10 \\
\hline \multicolumn{2}{|c|}{ Table 1 } \\
\hline \multicolumn{2}{|c|}{ Total } \\
\hline
\end{tabular}

\begin{tabular}{|c|c|}
\hline Group & Age (Yrs.) \\
\hline Group I & $0-10$ \\
\hline Group II & $11-20$ \\
\hline Group III & $21-30$ \\
\hline Group IV & $31-40$ \\
\hline Group V & $41-50$ \\
\hline Group IV & $51-60$ \\
\hline Group VII & Above 60 \\
\hline \multicolumn{2}{|c|}{ Table 2 } \\
\hline \multicolumn{2}{|c}{} \\
\hline
\end{tabular}

\begin{tabular}{|c|c|c|c|}
\hline $\begin{array}{c}\text { Age } \\
\text { Group }\end{array}$ & $\begin{array}{c}\text { Mean } \\
\text { Diameter of } \\
\text { Islets }(\boldsymbol{\mu})\end{array}$ & $\begin{array}{c}\text { Mean } \\
\text { Diameter of } \\
\text { Beta Cells } \\
(\boldsymbol{\mu})\end{array}$ & $\begin{array}{c}\text { Average No. } \\
\text { of Beta } \\
\text { Cells }\end{array}$ \\
\hline $0-10$ yrs. & 68 & 3.5 & 80 \\
\hline $11-20$ & 96 & 4 & 86 \\
\hline $21-30$ & 140 & 5 & 100 \\
\hline $31-40$ & 165 & 5.5 & 105 \\
\hline $41-50$ & 175 & 6 & 77 \\
\hline $51-60$ & 180 & 6.2 & 69 \\
\hline Above 60 & 200 & 6.5 & 40 \\
\hline \multicolumn{4}{|c|}{ Table 3 } \\
\hline
\end{tabular}

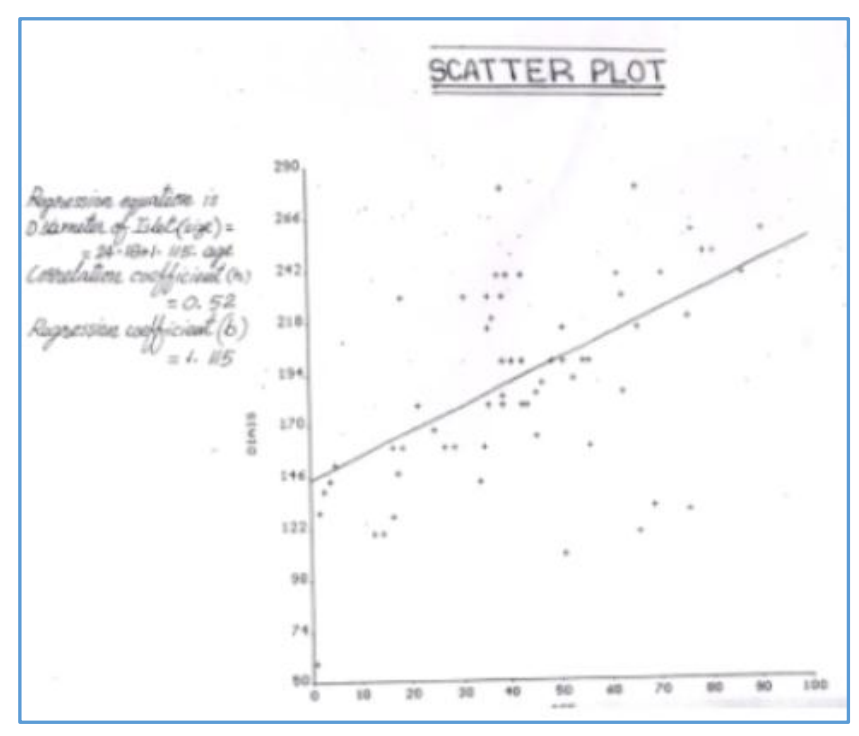

\section{DISCUSSION}

The age related changes in the islets of pancreas has attracted the attention of many researchers due to the increased incidence of diabetes mellitus from young age onwards. ${ }^{1}$ The present histological study emphasised the appearance of islets groups in various age groups. Each islet is surrounded by a thin capsule made up of reticular fibres. Islets were characterised by the central core of Beta cells and surrounded by Alpha cells and Delta cells. ${ }^{2,3} \mathrm{~A}$ six-fold increase in the number of Beta cells were observed in comparison to Alpha cells. 4,5 The above mentioned cell types and the capsules were clearly distinguished by Masson's Trichrome staining.6,7 Similar findings were reported by other scientists ${ }^{8}$ also.

The diameter of islets increased considerably and the number of islets decreased as age advanced. This finding is in conformity with the study of Hellman.9,10 No significant changes in the staining characteristics of islets in the children and adults were noticed in the present study as shown by others ${ }^{11}$ (Bryce and Munger, 1959). The mean diameter of beta cells differed in the islets of varying sizes. Such a change had been detected by Hughes. ${ }^{3}$ The occurrence of Beta cells more in the age group from 21 - 30 years suggests that this age group can be considered as an ideal age for islet donation. Similar findings were reported earlier by Gidding and Mordian. ${ }^{12}$

Giddings S. J. - 1995 reported insulin secretion diminished in response to glucose as age advances. In a 72-year-old man the islets showed more number of Beta cells, but the hospital records showed death was due to hypoglycaemia. ${ }^{13}$ In a 38year-old chronic alcoholic patient, the islets showed signs of pancreatitis as shown by Martini and Bode. ${ }^{14}$ Experiments done by Sarles et al in rats after chronic alcohol administration showed similar findings. According to Laidlow ${ }^{15}$ neoproliferation of Beta cells is thought to be the morphologic process underlying certain forms of hyperglycaemias seen in rare forms of hyperplasia of islets. ${ }^{14}$

The present study showed a gradual reduction in the number of Beta cells after 40 years of age, but their size increased gradually. This increase in cell size may be to counteract the reduced secretion of insulin as shown by the advancing age of individuals. ${ }^{16,17}$ These changes may not be uniform in all cases because certain chemicals like alloxan, genetic factors, composition of diet and autoimmune diseases can influence the age changes in islets. 18,19

In diabetic patients, the insulin intake multiplied the beta cells in order to secrete more insulin. As a result, the islets showed more number of beta cells and their size also increased. ${ }^{20}$ I could not make out any sexual differences in islets already studied, since in only three cases female specimens were obtained.

Alcoholic pancreatitis is not a strong risk factor for pancreatic cancer like genetically determined chronic pancreatitis. Pancreatitis could be triggered during pregnancy due to CYP24AI mutation. ${ }^{21}$ Association between IgEmediated allergic conditions and diabetes mellitus was also detected. ${ }^{22}$

Recently, Marabitaf and Islamms reported the expression of transient receptor potential channels in the purified human pancreatic beta cells. ${ }^{23}$

\section{CONCLUSION}

1. There was a gradual increase in the diameter of islets from birth to old age. 
2. The number of cells were gradually increased up to 40 years.

3. After the age of 40 years gradual reduction in the number of beta cells observed, but their size increased.

4. In a chronic alcoholic patient hyperplasia of islets, amyloid deposit, increase in islet diameter increase in the number of beta cells and alpha cells were observed.

The present work provides an opportunity to understand the normal histological appearance of islets at various age groups. This study also highlights the regular intake of sugar more than required may lead to hyperfunction of beta cells and their degeneration. Hence, reduced intake of sugar in younger age group may delay the onset of familial diabetes mellitus.

Over consumption of alcohol produces increased level of glucose in blood by gluconeogenesis and to counteract this, islets multiplies and the size and number of beta cells increases. At a later stage the number of alpha cells also increases and the person may develop alcoholic diabetes mellitus.

\section{Acknowledgements}

I thankfully acknowledged the guidance and valuable suggestions of Dr. Aleyamma Fenn, T.K. MS Professor and Head, Department of Anatomy, Govt. Medical College, Palakkad and Dr. K.R. Chandramohanan Nair, Senior Scientific Officer in Department of Anatomy, Govt. Medical College, Trivandrum.

\section{REFERENCES}

1. Berry DC, Williams W, Hall EG, et al. Imbedding interdisciplinary diabetes group visits into a communitybased medical setting. Diabetes Edu 2016;42(1):96-107.

2. Bencosome SA. The histogenesis and cytology of the pancreatic islets in the rabbit. American Journal of Anatomy 1995;96:103-51.

3. Herderc, Faeroch K, Carstensen, et al. Lowe G cytology of endocrine glands. Eur J Endocrinol 2016:106-52.

4. Rhoten WB. The cell population in pancreatic islets of amphisbaenidae--a light and electron microscopic study. Anat Rec 1970;167(4):401-23.

5. Saguchi S. Cytological studies of langerhans with special reference to the problem of their relation to the pancreatic acinous tissue. American journal Anat 1950:28.

6. Bayley JM. Staining methods for the islets of langerhans. J Patho and Bact 1937;44(1):272-6.
7. Ferner H, Chenius SW. Journal die cytogenesis des insel systems beins menschen. Z Zell forsch 1950;35:147.

8. Gomori G. Observations with differential stains on human islets of langerhans. American Journal Patho 1941;17(3):395-406.

9. Hellman B. The volumetric distribution of the pancreatic islet tissue in young and old rats. Acta endocrinol 1959;31(1):91-106.

10. Sergeyeva MA. Microscopic changes in the islands of langerhans produced by sympathetic and parasympathetic stimulation in the cat. Anant Rec 1940;77(3):297-317.

11. Kaung HC, Elde RP. Distribution and morphometric quatitation of pancreatic endorine cell types in the frog, rana pipiens. Ant Rec 1980;196(2):173-81.

12. Giddings SJ, Carnaghi LR, Mooradian AD. Age related changes in pancreatic islet cell gene expression. Metabolism 1995;44(3):320-4.

13. Fujita T. D cell, the third endocrine element of the pancreatic islet. Arch Histolo Jap 1968;29(1):1-40.

14. Colson S, Cote J, Genbles. Hamel V microscopy of pancreatic islets in diabetic patients. Diabetes Edu 2016:15-40.

15. Laidlaw GF. Nesidoblastoma the islet tumor of the pancreas. American Journal 1938;14(2):125-34.

16. Bloom W. A new type of granular cell in the islets of langerhans of man. Anat Record 1931;49(4):363-71.

17. Lacy PE. Electron microscopy of the beta cells of the pancreas. American Journal Medicine 1961;31(6):851-9.

18. Williamson JR, Lacy PE. Electron microscopy of islet cells in alloxan treated rabbits. Arch Patho 1959;67(1):102-9.

19. Goldner MG. Alloxan diabetes-its production and mechanism. Acta med 1945;21(1):44-55.

20. Woerner CA. Studies of the islands of langerhans after continuous intravenous injection of dextrose. Anato Rec 1938;71(1):33-57.

21. Kuskinen MK, Helmineno, Matomaki J, et al. Corelative study of pancreatic islets in normal and diabetic patients. Eur J Endorinology 2015:76-100.

22. Thomas TB. Cellular components of the mammalian islets of langerhans. American Journal Anant 1937;62(1):31-57.

23. Tian YA, Jonson G, Ashcroft SJ. Sulfonylureas enhance exocytosis from pancreatic beta cells by a mechanism that does not involve direct activation of protein kinase C. Diabetes 1998;47(11):1722-6. 